\title{
Child Care in Spain after 1975: the Educational Rationale, the Catholic Church, and Women in Civil Society ${ }^{\star}$
}

\author{
Celia Valiente
}

\section{Introduction}

In Spain today, preschool attendance rates are among the highest in the European Union (EU) for children aged three, four and five (96 percent, 100 percent, and 100 percent respectively). In contrast, Spanish child-care attendance rates are comparatively low for children aged two and under. Why is Spain at the vanguard of the European Union (EU) regarding preschool attendance rates for children aged three, four and five years? After briefly describing in the first section of this chapter the main Spanish preschool policies since 1975, in the second section I present the analytical framework to answer this question. In the third, fourth and fifth sections, I explain that in Spain most child-care provision has historically been part of education policy. Between the mid-1930s and 1975, Spain was governed by a right-wing authoritarian regime headed by General Francisco Franco. A transition to democracy and a stable democracy followed the dictatorship. After 1975, policy-makers continuously expanded the programmes that were already in place: public preschool services for children under the age of mandatory education (six years). In postauthoritarian Spain, the context was favourable for the increase in public preschool supply because the Catholic Church, which is a principal actor in education, is interested in the expansion of preschooling, provided that part of it is private and subsidised by 
the state. The major presence of women in civil society and the increasing strength of the women's movement mean that women now form a visible electorate that politicians usually take into consideration. As a result, policy-makers tend to support policies that could be seen as favourable to women, such as an expansion of public child care.

Finally, in the sixth section of this chapter, I argue that preschool is not child care, and therefore, in Spain, working parents cannot rely only on preschool to combine work and family. I also identify two major barriers to an expansion of care in centres for the under-twos: societal views about the best care options for infants and toddlers, and a pool of grandmothers and immigrants who take care of very young children at home. Secondary literature and published primary data are the main sources of this chapter.

\section{Analytical framework}

Social policy is usually expanded and more infrequently restricted. This dynamic is captured by a concept used by social scientists: pathdependency (Pierson, 2000; Rose, 1990). According to path-dependency analyses, in a given policy area several courses of action are possible while politicians are initially trying to solve a problem. But once a course of action (or path) is chosen, it is easier for policy-makers to advance a bit farther along the path than to start a completely new course of action. Several reasons explain the continuity of any given policy along the same path, among others that some individual and collective actors are interested in maintaining the status quo. These actors are the recipients of the social programme and the bureaucrats who administer it. Because these individual and collective actors share a specific goal (the maintenance and even expansion of the social policy), they can mobilise with relative ease to achieve this goal. At some point in time, dismantling the existing policy and/or initiating a new course of action may be almost impossible.

At least three insights of the path-dependency literature are worth noting. First of all, time matters, and past decisions have consequences on future decisions. Thus, while studying policy-making at any given moment, it is also necessary to analyse the actions of former politicians in the same policy area. Second, although policy-makers at any given point in time tend to follow the same path as their predecessors, the results of policy-making may be different at different times. For instance, politicians may initiate a social policy that covers only a 
politicians include more categories of beneficiaries within the social scheme. Eventually, the whole population may be covered by such a scheme. Thus, a programme for only a small fraction of the population may evolve after a long period of time into a very different programme, such as a universal service. Third, context matters too. Some contexts are more favourable than others to an intense expansion of pre-existing policies, for instance, if numerous actors are interested in such an expansion, and no major actor wants to dismantle the pre-existing policy.

With respect to the more specific comparative literature on welfare states, in general and with important exceptions, researchers have not studied education policy. Recently, education has been included in some welfare state studies (see, for instance, Esping-Andersen, 2007). This is the approach used in this chapter. Like other social policies, education may (or may not) help to erode social inequalities. Therefore, there is no reason to ignore education in studies of social policy-making.

The literature on the origin and development of welfare states in Western countries has usually privileged the study of socioeconomic development and class politics as primary forces causing the establishment and expansion of social policy (Castles, 1994, p. 19; Daly, 1999, p. 106; van Kersbergen, 1995, p. 1). The role played by organised religion in social policy-making has received less attention. In Western countries in modern times, states and churches have fought for control of the education system. Therefore, the study of organised religion is especially important to understanding education policy.

Spain is a culturally homogeneous Catholic country. After the expulsion of Jews in 1492 and of Muslims soon afterwards, no significant religious community other than the Catholics has been openly active in Spain in the last four centuries. The majority of adult Spaniards consider themselves Catholic (77.6 percent in July 2007). ${ }^{1}$ Although the number of practising Catholics is much lower than the number of selfdeclared Catholics, it is significant: 15.8 percent of those self-declared Catholics or believers of other religions affirmed that they attended religious services (excluding social events such as weddings, first communions, or funerals) almost every Sunday or religious holiday, and 2.2 percent attended on various days during the week (Centro de Investigaciones Sociológicas, 2007). Part of the literature on the origin and development of welfare states identifies Christian democratic parties as principal actors in the translation of Catholic social doctrine into actual social policy-making (Morgan, 2006; van Kersbergen, 1995). ${ }^{2}$ 
representation, because no major Christian democratic party or trade union exists (Casanova, 1993).

The literature on welfare states in the Western world argues that the influence of Catholicism on social policy-making has been very complex. A correlation has been found between Catholicism and the level of expenditure on social security transfers at some points in history (Castles, 1994, pp. 24-26). Catholicism indirectly influences the type of social policy, because Catholic social doctrine manifests at least three marked preferences regarding the sort of social policy to be established. Firstly, social provision should be implemented by organisations of civil society (especially those of the Catholic Church). Secondly, social provision should preserve status differences in society, for instance, because of the existence of different schemes for different types of workers. Thirdly, social provision should help families care for their members basically by providing them with income in case the head of the family is unable to earn a sufficient wage in the labour market, rather than replacing families in their caring functions by providing them with caring services. Regarding social policies that particularly affect women, the Catholic hierarchy has historically supported the view that married women's place is mainly in the home taking care of their relatives. Thus, social policy should not interfere but reinforce the performance of this role (Castles, 1994; Daly, 1999; Morgan, 2006; van Kersbergen, 1995).

\section{Child-care policies in Spain after 1975}

Child care can be thought of as a labour-market, gender-equality or education policy. In Spain before and after 1975, education has been the predominant rationale. Since 1975 , the main child-care policy has been an ever increasing supply of public preschool programmes for children under the age of mandatory schooling (six). These programmes are free of charge, full-day, and administered within the policy area of education authorities. The absolute number and proportion of children who attend preschool programmes in public centres has increased intensively since 1975 . While this type of centre was attended by 347,026 children younger than six in academic year 1975-1976, this figure had nearly tripled (991,626 children) by academic year 2006-2007. Seen from another perspective, in academic year 1975-1976, more than a third (38 percent) of children enrolled in preschool education attended public centres. In academic year 2006-2007, this proportion was nearly two-thirds (64 percent). The expansion of the supply of places in public 
child care has taken place in a context characterised by the existence of a private sector. In academic year 1975-1976, the number of children enrolled in preschool education who attended private centres was 573,310 , while in academic year 2006-2007 the figure was 546,341. ${ }^{3}$

In part as a result of the policy just described, Spanish preschool attendance rates (in public and private centres) for three-, four-, and five-year-olds are among the highest in the EU at 96 percent, 100 percent and 100 percent respectively (Ministerio de Educación y Ciencia, 2006; provisional data for academic year 2006-2007). In academic year 20022003, four EU countries (Belgium, France, Italy and Spain) had 100 percent of four-year-old children enrolled in pre-primary or primary education, while the EU-25 average was 14 points lower ( 86 percent). In the same academic year, the Spanish participation rate of threeyear-old children in pre-primary or primary education (95 percent) was exceeded only by those of Belgium, France and Italy (100 percent in each of the three countries), and was 27 points higher than the EU-25 average (68 percent) (Andrén and Schmidt, 2005, pp. 8-9). Conversely, the proportion of Spanish children aged two or younger cared for in public or private centres is comparatively low: 4 percent for children younger than one year, 16 percent of children aged one year, and 30 percent for those two years old (academic year 2005-2006; Ministerio de Educación y Ciencia, 2007). ${ }^{4}$

In democratic Spain, besides the pronounced expansion of the supply of public preschool programmes, the other most important change in the area of child-care policy has been territorial decentralisation. Under Franco, the state was highly centralised, but during the transition to democracy a broad process of devolution of powers from the central state to the regions (less so to municipalities) was set in motion. Since the early 1980 s, some regional governments have been acquiring responsibilities previously assigned to the central state (for instance, education). The process of devolution of full responsibilities for education to all regions was completed in $2000 .^{5}$

\section{The educational rationale of Spanish child-care policy}

As already noted, in Spain, child care has always been mainly an education policy independent of the political regime governing the country. In Franco's Spain, the gender equality argument was out of the question, since the regime actively opposed the advancement of women's rights and status. Divorce was abolished and the selling and 
advertising of contraceptives were criminalised. Abortion was defined as a crime subject to a prison sentence. According to the official doctrine of the dictatorship, the ideal family was a hierarchical unit, because the authority within it rested with the father, who was supposed to be its sole (or at least its main) supporter. Motherhood was defined not only as the main family duty of women but also as women's main obligation towards state and society. The role of mothering was perceived as incompatible with other activities, such as waged work. During the first phase of the Franco regime (between the second part of the 1930s until the late 1950 s - early 1960s), the state took measures to prevent women's labour outside the home. For example, a married woman needed her husband's permission before signing a labour contract and engaging in trade. During the second phase of the Franco regime (between the late 1950s - early 1960s and 1975), policy-makers approved some liberalisation measures related to women's status, such as the abolition of some obstacles regarding paid employment (for instance, banning married women from working and prohibiting women from practising some law professions) (Morcillo, 2000; Nash, 1991).

Regarding children under the age of mandatory education, when Franco died in 1975, the central state already had a preschool policy within the policy area of education. A principal institution to formulate this policy was functioning: the Ministry of Education. (Limited) premises and staff to implement this policy also existed: preschool teachers and classes for children under the age of six in public schools. The path-dependency approach to policy analysis suggests that, after 1975 , central state policy-makers (and later regional authorities) found it easier to expand what was already in place than to invent a completely new policy from scratch. In fact, since the transition to democracy, the supply of places in public preschool centres has been expanded by parties of different ideological colours while in office at the central state level (although for different reasons): the centre-right coalition of parties Union of the Democratic Centre (Unión de Centro Democrático, UCD) up to 1982, the social-democratic Spanish Socialist Workers' Party (Partido Socialista Obrero Español, PSOE) between 1982 and 1996, the conservative People's Party (Partido Popular, PP) between 1996 and 2004, and again the PSOE since then. In the 1970s and 1980s, public preschool places were provided especially for children aged four and five, while in the 1990 s and after 2000 these places were also increasingly given to children aged three.

Governments formed by the UCD, PSOE and PP have understood

preschool services as a necessary step for Spain to catch up with 
surrounding countries since most $\mathrm{EU}(-15)$ member states are economically more developed. All three governing groups have thought that one of the reasons for Spain's relative backwardness was an education deficit. The social-democratic PSOE promoted public preschool mainly to diminish class inequality. Historically, access to nonmandatory education was sharply differentiated by class (de Puelles Benítez, 1999, pp. 368-369; McNair, 1984, p. 47; Medina, 1976, pp. 123, 130). The conservative PP maintained and increased the supply of publicly supported preschool. In the context of strong electoral competition from the PSOE, the conservatives did not want to be seen by the electorate as a party that defended the interests of affluent citizens who tend to use private child-care and preschool programmes (Valiente, 2002, p. 63; 2003 , p. 289). For the same reasons, regional governments of different ideological colours continued to expand public preschool programmes when powers on education were transferred from the central state to the regions. ${ }^{6}$

\section{The Catholic Church}

The Catholic Church is a key player in education, controlling the majority of private centres (but not all). Private centres provide educational services to approximately a third of non-university students (Ministerio de Educación y Ciencia, 2006, p. 3). In general, the Catholic Church is interested in the expansion of education, provided that a substantial part of it is private and subsidised by the state.

Most private provision of non-university education is subsidised by the state. In academic year 2004-2005, 84 percent of non-university students in private education were pupils of subsidised centres (centros privados concertados). In the same academic year, 72 percent of nonuniversity students in subsidised private education were pupils attending religious centres. In exchange for state funding, subsidised private centres must use the same criteria as public centres to select students if the number of applicants exceeds the number of places; they must also supply education free of charge (this does not include extracurricular activities, school meals, or textbooks); and they must allow parents, students and school staff to participate in school decision-making. State subsidies are a very important source of income for providers of subsidised private education. On average, in academic year 2004-2005, the state covered 75 percent of current expenses of subsidised private centres (Instituto Nacional de Estadística, 2007a, p. 4). Up to the 1990s, 
then the state has increasingly subsidised private preschool education as well.

In sum, in postauthoritarian Spain, the Church has continuously demanded (and obtained) subsidies for its private education provision, including preschool services. In this way, two of the preferences of social Catholic doctrine have been satisfied. First, (part of) social policy is administered by organisations controlled by the Church, that is, confessional private schools. Second, in general and with important exceptions, access to private education is related to social class. Thus, the existence of a private education sector means the preservation of status differences within society.

In postauthoritarian Spain, the Catholic Church has also constantly demanded that the state grant religion academic status in the school curriculum (Bonal, 2000, pp. 205-206; McNair, 1984, p. 144). Contrary to expectations derived from the literature on the origin and development of welfare states, in the last three decades, the Catholic hierarchy has not vocally and continuously argued that preschool or child care is detrimental for children, or that mothers should take care of their offspring at home. It is not easy to explain why the Catholic Church has behaved in this way. Probably, the fact that the Church controlled a significant sector of non-university education made the Church hierarchy more interested in expanding this sector than in locking women and their very young children in their homes.

It is important to note that the ascendancy of the Church in politics (and society) has been severely declining at least since the transition to democracy. Spain now belongs to the group of Western countries with secularised polities (and societies). The (imperfect) separation of church and the Spanish state is reflected in the Constitution. According to Article 16, Spain is a nondenominational state based on religious freedom. Nevertheless, this very same article also states that 'public authorities will keep in mind the religious beliefs of Spanish society' (that is, Catholicism). Article 16 also refers to the desirability of cooperation between the state and the Catholic Church and the remaining denominations. The state's special treatment of the Catholic Church is mainly reflected in important state transfers, tax exemptions and financial support to most Catholic schools, hospitals, centres of social action and patronage for the arts. Thus the Catholic Church in Spain is not self-supporting but needs state money for its economic survival. The Catholic Church accepted the principle of nonconfessionality of the Spanish state and the constitutional regulation of state-church relations (Bedoya, 2006; Casanova, 1993, p. 117; Linz, 1993, p. 35). 
The Catholic Church does not agree with some laws regulating moral matters, such as the laws that legalised divorce (1981), liberalised abortion (1985), or permitted gay marriage (2005), but it has not made an enormous effort to have them revoked. Resistance by Catholics to these public policies has been more moderate in Spain than in other Western countries. The Catholic Church is not involved in the main political controversies of the country (with the possible exception of the nationalist question in the Basque country) and does not control the government agenda, but is not silent on matters the Church considers important (education and moral issues such as abortion and sexuality, among others) (Linz, 1993, pp. 32-48).

The (imperfect) separation of church and state is a characteristic of the democratic regime established after the end of the dictatorship in 1975, but not of the right-wing authoritarian regime headed by Franco. During the first phase of the Franco regime, the church and the political regime supported each other. Catholicism was the official religion of the country. Freedom of worship was abolished. The state gave the church the prerogative of managing all matters regarding marriage and the separation of married couples. Catholic marriage was mandatory, with very few exceptions. The state allowed the Catholic Church to control part of the education system: a significant number of primary and secondary schools, but not most universities, which had been under state control at least since the mid-nineteenth century (McNair, 1984, pp. 18-19). In all primary and secondary schools, the state made religious teaching and religious practices mandatory and education had to conform to the teachings of the Catholic Church. The Church was given the right to inspect private and public centres (McNair, 1984, pp. 28-29). Sex-segregated schools were the norm, and boys and girls not only attended different schools but also had different curricula. The state supported the Catholic Church financially, and the Church was exempt from taxation. In turn, the Church supported the authoritarian regime, provided it with legitimacy, and declared the civil war (19361939) a crusade between supporters of Christianity (Franco's followers) and the unfaithful and immoral (the Republicans). Some of the administrative cadres of the Francoist state came from Catholic lay organisations such as the Asociación Católica Nacional de Propagandistas and later Opus Dei. Catholic hierarchies occupied a salient place in official governmental acts. State authorities ex officio attended religious ceremonies (Casanova, 1993, pp. 107-108; Linz, 1993, pp. 9-25).

Relations between church and state changed in the second phase of the Franco regime. Part (only a part) of the Church distanced itself from 
the regime, criticised the position and actions of the Church in the civil war, and even gave protection and support to political dissidents. Catholics became members of groups and parties of all ideological colours in opposition to the dictatorship. Thanks to this progressive distancing of a part of the Church from the political regime, when Franco died in 1975, the Church could align itself with other political and social forces in building a new democratic state (Casanova, 1993, pp. 114-117; Linz, 1993, pp. 25-32).

\section{Women in civil society and the women's movement}

Women are increasingly active in organisations of civil society, whether in women-only groups or in mixed associations. Thus, women now constitute a visible electorate that politicians often take into consideration when calculating what policies they support or oppose. As for the large presence of women in mixed associations in civil society, for example, on average, women outnumber men in the so-called third sector dedicated to social causes (Pérez Díaz and López Novo, 2003, pp. 214-217, 231-233, 241-242). The women's movement is made up of one branch which is explicitly feminist and another branch which is not. The latter is formed by housewives' organisations, widows' associations, mothers' movements, and cultural and religious associations, among others. This branch is currently thriving in terms of number of members and degree of activity (Ortbals, 2004).

The first groups of the explicitly feminist branch of the women's movement (hereafter referred to as the feminist movement) were set up in the late 1960s and early 1970s in the period of liberalisation of the authoritarian political regime. Many of the first feminists were active in the opposition to the dictatorship, where they encountered illegal leftwing political parties and trade unions. These have been the (uneasy) allies of the feminist movement ever since (Threlfall et al., 2005).

In the last three decades, the feminist movement has influenced gender equality policy-making mainly due to its involvement with left-wing political parties. Many feminists mobilised within both feminist groups of civil society and left-wing political parties. When these reached power, some of their feminist activists and leaders occupied decision-making positions in the state from which they could advance an agenda of gender equality. Alternatively, feminists within left-wing political parties endlessly pressurised male activists and leaders to take gender equality into consideration when choosing 
their policy objectives (Threlfall, 1996; Threlfall et al., 2005). The feminist movement has also intervened in the gender equality policy area mobilising public opinion in favour of the need to improve women's status (Trujillo Barbadillo, 1999).

Since the transition to democracy, child care has been an issue of only moderate priority for the feminist movement. Child care helps women to combine work and family. Therefore, feminists in all Western countries including Spain have demanded child-care services. But in Spain, the existence of the right-wing authoritarian regime helped move Spanish feminists away from issues such as motherhood and child care later on. After $\mathbf{4 0}$ years of being literally bombarded with the idea of mothering and caring as the most important task in women's lives, the last thing Spanish feminists wanted to do after the dictatorship was to pay a lot of attention to the issues of motherhood and child-rearing. Women's liberation was then understood as opening the range of concerns that define women's lives, such as waged work, political participation, or control of their bodies. This definition carefully skirts the place of motherhood and child care in the life of the newly liberated Spanish (Valiente, 2002, p. 65; 2003, p. 288).

Even though child care has not been a top priority for the feminist movement through the whole postauthoritarian period, preschool is seen by important sectors of public opinion not only as an education policy but also as a policy favourable to women. This is so because preschool is used (together with other options) by working parents to combine work and family, and an increasing number of women work for pay. Thus, an expansion of public preschool services is usually perceived by broad sectors of the citizenry as a policy that helps women. Cuts in public preschool provision would be interpreted as a policy against women and therefore out of the question in a country where women form an ever increasing part of civil society, and both branches of the women's movement are increasingly visible.

\section{Limitations of preschool and future challenges}

As stated earlier, in Spain, the supply of places in free public preschool was increased substantially over the last three decades. Nevertheless, the very definition of these institutions as schools rather than child-care centres has limited their utility for working parents. Preschool programmes provide solid educational services for children aged three to five years. Addressing the educational needs of young 
children (from all social classes) is a laudable goal, and its achievement should be celebrated. However, preschool programmes cannot be used by parents as perfect substitutes for child care, because preschool holidays are considerably longer than work holidays and preschool hours are shorter than the work hours for full-time jobs (sometimes much shorter and interrupted by a break). Even if the Spanish women's employment rate (51.6 percent) is lower than the EU(-25) average ( 56.5 percent), most Spanish women who work for wages (77.3 percent) have full-time jobs (third quarter 2005 data; Romans and Hardarson, 2006, pp. 3-5). Policies other than preschool education to help parents combine work and family are seriously underdeveloped in Spain (León, 2007).

At least two obstacles will hinder the expansion of child-care services in the near future for the under-threes: widespread assumptions regarding the centrality of mother-care for small children; and an important number of grandmothers and immigrants who provide child care. It is still commonly believed by both women and men in Spain that care by the mother is indispensable at least at the beginning of the child's life, and that the (full-time) employment of mothers jeopardises the upbringing of very young children. For instance, in a 2002 survey, slightly over half of the adult population of both sexes strongly agreed or agreed with the statement that a preschool child will suffer if his/her mother works (data from Morgan, 2008, p. 29).

When mothers do not stay at home day and night to take care of their children, the second preference of many parents is that another woman, often a grandmother, replaces the working mother in the home. Grandmothers are frequently available to look after their grandchildren because the majority of women in these age groups are full-time housewives, and many young parents live near their parents. Other children are also cared for by domestic workers, who also perform household duties. This option is only available to members of the upper-middle or upper classes who can afford these services. Immigrants are available to perform this type of job. On 1 January $2007,45.12$ million people lived in Spain, of whom around 10 percent were foreigners (Instituto Nacional de Estadística, 2007b; provisional data). Labour market experts estimate that approximately 600,000 people (overwhelmingly women) are employed as domestic workers in Spain (El País 21 May 2007, p. 102). However, the official figure is lower: in July 2007 , around 271,500 people contributed to the special scheme of social security for domestic workers (Ministerio de Trabajo y Asuntos 


\section{Conclusion}

In this chapter, I have shown that the main child-care public policy after 1975 has been an ever increasing supply of full-day, public preschool free of charge. This policy already existed before 1975 although it was considerably less developed than it is today. As the literature on path-dependency would predict, pre-1975 public preschool provision was expanded in postauthoritarian Spain by governments of different ideological colours at the central state level and later at the regional level. In part as a result of this policy, Spain is at the vanguard of the EU regarding preschool education coverage for children aged three (96 percent), four (100 percent) and five (100 percent). In the last years of the dictatorship, the majority of children under six did not attend preschool. In academic year 1971-1972, preschool attendance rates for children aged three, four, and five were 12 percent, 42 percent, and 61 percent respectively (Pérez Peñasco, 1976, p. 224). Thus, by expanding pre-existing programmes, postauthoritarian policy-makers converted a programme of limited coverage into a nearly universal scheme.

From the literature on path-dependency, one can infer that context matters while explaining the intensity with which policy-makers continue along the same path as their predecessors. In postauthoritarian Spain, the intense expansion of public preschool services can be understood if one considers the fact that the Catholic Church is interested in the expansion of preschool services, provided that part of them are private and subsidised by the state. This policy is perceived as beneficial to women in a country where more and more women are active in civil society.

I have also identified some factors that mitigate the demand of public child care for children aged two or under. An important share of the population thinks that very young children should be taken care of at home. Mothers who do not work for wages, grandmothers and immigrants are providing this type of child care in different types of families. Cultural specificities and class differences are at play here. On the one hand, many Spanish people find it natural for grandmothers to take care of their very young grandchildren while the mothers of these children are working for pay. In other EU countries, many citizens think that family obligations should not be stretched that far (Millar and Warman, 1995). On the other hand, in Spain, families in the uppermiddle and upper classes prefer their toddlers and infants to be cared for at home by domestic workers rather than in centres by professional staff, while exactly the opposite is true in other EU member states. In 
Spain (and possibly other Mediterranean countries), most members of the upper-middle and upper classes feel comfortable when being served by others at home, while in other countries (for example, the Nordic states) most members of the very same classes feel quite uncomfortable and even embarrassed in the same situation. To investigate these and other cultural dimensions beneath the surface of child-care policies is one of the next steps in the research on social policy from a comparative perspective.

\section{Notes}

*This chapter contains research undertaken by the project 'Gender and citizenship in multicultural Europe: The impact of the contemporary women's movements (FEMCIT)' financed by the European Commission's Sixth Framework Program (EC contract number 028746-2).

1. In the same opinion poll, 1.4 percent of the interviewed identified themselves as belonging to other religions, 12.4 percent non-believers and 6.8 percent atheist, and 1.8 percent did not answer.

2. For a critique of the importance given to Christian Democratic parties by this literature, see Castles (1994, pp. 23-24) and Daly (1999, p. 106).

3. Calculated by Celia Valiente from data of Instituto Nacional de Estadística (1977) pp. 101-103; Ministerio de Educación y Ciencia (2006) p. 3 (provisional data for the academic year 2006-2007).

4. See comparative data in Morgan (2008), pp. 31-32.

5. Other child-care policies such as tax exemptions for child-care expenses are much less important than the supply of preschool places in public centres. Due to space constraints, only the latter is analysed in this chapter.

6. However, some regional governments were more committed to public preschooling than others. Due to space constraints, this paper does not analyse regional variations.

\section{Bibliography}

B. Andrén and P. Schmidt, 'Education in Europe: Key Statistics 2002-2003', Statistics in Focus: Population and Social Conditions, 10 (2005) 1-12

J. G. Bedoya, 'Las cuentas del catolicismo español', El País (30 September 2006) 43

$\mathrm{X}$. Bonal, 'Interest Groups and the State in Contemporary Spanish Education Policy', Journal of Educational Policy, 15, 2 (2000) 201-216

J. Casanova, 'Church, State, Nation, and Civil Society in Spain and Poland', in S. A. Arjomand (ed.), The Political Dimensions of Religion (Albany, New York: State University of New York Press, 1993), 101-153

F. G. Castles, 'On Religion and Public Policy: Does Catholicism Make a Difference?', European Journal of Political Research, 25, 1 (1994) 19-40

Centro de Investigaciones Sociológicas, Study Number 2,728, Iuly (2007). Retrieved 8 August 2007 at www.cis.es 
M. Daly, 'The Functioning Family: Catholicism and Social Policy in Germany and Ireland', Comparative Social Research, 18 (1999) 105-133

M. de Puelles Benítez, Educación e ideología en la España contemporánea (Barcelona: Labour, 4th ed., 1999)

El País (21 May 2007) 102

G. Esping-Andersen, 'Investing in Children and Their Life Chances', Paper presented at the International Conference Welfare State and Competitivity: the European Experience and the Agenda for Latin America, Fundación Carolina, Madrid, 26-27 April (2007)

Instituto Nacional de Estadística, Estadística de la enseñanza en España: Curso 1975-76 (Madrid: Instituto Nacional de Estadística, 1977)

Instituto Nacional de Estadística, Notas de prensa-19 de julio de 2007: Encuesta de Financiación y Gastos de la Enseñanza Privada, curso 2004-2005 (2007a). Retrieved 27 August 2007 at www.ine.es

Instituto Nacional de Estadística, Notas de prensa-11 de junio de 2007: Avance del Padrón Municipal a 1 de enero de 2007, datos provisionales (2007b). Retrieved 27 August 2007 at www.ine.es

K. van Kersbergen, Social Capitalism: A Study of Christian Democracy and the Welfare State (London: Routledge, 1995)

M. León, 'Speeding Up or Holding Back? Institutional Factors in the Development of Childcare Provision in Spain', European Societies, 9, 3 (2007) 315-337

J. J. Linz, 'Religión y política en España', in R. Díaz-Salazar and S. Giner (eds), Religión y sociedad en España (Madrid: Centro de Investigaciones Sociológicas, 1993), 1-50

J. M. McNair, Education for a Changing Spain (Manchester: Manchester University Press, 1984)

A. Medina, 'Problemática de la educación preescolar en España', Revista de Educación 247 (1976) 111-134

J. Millar and A. Warman (eds), Defining Family Obligations in Europe (Bath: University of Bath Social Policy Papers 23, 1995)

Ministerio de Educación y Ciencia, Datos y cifras, curso escolar 2006/2007 (2006) Retrieved 3 August 2007 at www.mec.es

Ministerio de Educación y Ciencia, Estadística de las enseñanzas no universitarias: Resultados detallados del curso 2004-2005 (2007) Retrieved 3 August 2007 at www.mec.es

Ministerio de Trabajo y Asuntos Sociales, Resumen últimos datos (2007) Retrieved 27 August 2007 at www.mtas.es

A. G. Morcillo, True Catholic Womanhood: Gender Ideology in Franco's Spain (Dekalb: Northern Illinois University Press, 2000)

K. J. Morgan, Working Mothers and the Welfare State: Religion and the Politics of Work-Family Policies in Western Europe and the United States (Stanford: Stanford University Press, 2006)

K. J. Morgan, 'Towards the Europeanisation of Work-Family Policies? The Impact of the EU on Policies for Working Parents', in S. Roth (ed.), Gender Issues and Women's Movements in the Enlarged European Union (London: Berghahn, 2008, forthcoming)

M. Nash, 'Pronatalism and Motherhood in Franco's Spain', in G. Bock and P. Thane (eds), Maternity and Gender Policies: Women and the Rise of the European Welfare States, 1880s-1950s (London: Routledge, 1991), 160-177 
C. D. Ortbals, Embedded Institutions, Activisms, and Discourses: Untangling the Intersections of Women's Civil Society and Women's Policy Agencies in Spain (PhD dissertation: Indiana University, 2004)

V. Pérez Díaz and J. P. López Novo, El tercer sector social en España (Madrid: Ministerio de Trabajo y Asuntos Sociales, 2003)

A. Pérez Peñasco, 'Educación', in Fundación Foessa (ed.), Estudios sociológicos sobre la situación social en España 1975 (Madrid: Euramérica, 1976), 195-344

P. Pierson, 'Increasing Returns, Path Dependence, and the Study of Politics', American Political Science Review 94, 2 (2000) 251-267

F. Romans and Ó. S. Hardarson, 'Labour Market Latest Trends - 3rd Quarter 2005 Data: The Employment Rate Continues to Rise', Statistics in Focus: Population and Social Conditions 6 (2006) 1-8

R. Rose, 'Inheritance Before Choice in Public Policy', Journal of Theoretical Politics, 2, 3 (1990) 263-291

M. Threlfall, 'Feminist Politics and Social Change in Spain', in M. Threlfall (ed.), Mapping the Women's Movement: Feminist Politics and Social Transformation in the North (London: Verso, 1996), 115-151

M. Threlfall, C. Cousins and C. Valiente, Gendering Spanish Democracy (London and New York: Routledge, 2005)

G. Trujillo Barbadillo, 'El movimiento feminista como actor político en España: El caso de la aprobación de la Ley de despenalización del aborto de 1985', Paper presented at the Annual Meeting of the Spanish Association of Political Science and Public Administration, Granada, Spain (1999)

C. Valiente, "The Value of an Educational Emphasis: Child Care and Restructuring in Spain since 1975', in S. Michel and R. Mahon (eds), Child Care Policy at the Crossroads: Gender and Welfare Restructuring (New York and London: Routledge, 2002), 57-70

C. Valiente, 'Central State Child Care Policies in Postauthoritarian Spain: Implications for Gender and Carework Arrangements. Gender \& Society, 17, 2 (2003) 287-292 